\title{
Christine Japely
}

\section{Duty, Opportunity, Lost Cat}

\author{
"Please Help Me!"-LOST CAT-Lost from Vet. \\ Just de-clawed. Two year old black and white \\ female-petite. Named Sutu. If sighted \\ call 985-9485.
}

I pick the photocopy off the front porch, glance at the cat's face staring out at me, and almost crumple the sheet immediately (in the interest of conserving energy for the real business of life). But I hesitate. "Please Help Me!" begs the cat, the cat named Sutu. And so I toss the flier near the jumble by the telephone. I've got to perform some social duties, after all. I can't persist in always being such a curmudgeon. Sutu. That's a splendid name for a cat. And the nine year old, my daughter, will be interested; she's more community-minded than I am. She writes letters to Bill Clinton and Hillary and she waits for the form letter replies. "I need a handsome dad like Bill Clinton," she mutters darkly in my direction. I am stunned at her perspicacity, for yes, she's right: he's attractive, every excessive ounce of him, every groomed and gleaming energetic iota. I remember myself at about my daughter's age, no, a bit younger, thinking Richard Nixon was goodlooking and mentioning it to my mother. I can still see the appalled look she gave me. "No, no," she said, "he's the handsome one, that one," she snapped, making stabbing jabs at the TV image of a debating Jack Kennedy. I hung around the living room through all those debates so I could steal glances now and then at Tricky Dicky. My mom was wrong. Tricky was far more attractive. I was five or six. Tricky was a dreamboat.

Maybe three days later I am in my yard cooing at all the pink buds on my carnation plant, the dozens of opening Shasta daisies, the upwardwinding and fragile-pastel sweet peas. A major heat wave is on the way and so I'm watering with care and drinking gin, and as I finish I toss the hose back behind me and I startle a creature that bounds 
quickly away, a small black and white cat. Oh. It's that one. That cat with the pretty name. I watch it disappear off into a side corner of the yard. My hose throw spooked it. I put down my glass, run into the house, search for and find that notice, dial the number. An old lady answers. "Ah, the cat," she says. "Oh wonderful. Wait. Let me get my mother." And the phone is handed from a, say, sixty year old to a perhaps eighty year old. "The vet's office did it," she tells me. "Someone left a door open." I listen to her voice quaking in rage. "She was in to be declawed, and some foolish person didn't latch the office door." She pauses and there is a moment of allowing the angry waves to quell a bit. My heart has flown into my throat. But this is just a tiny disaster, a mere speck. I give my address. "The vet people will come," the old lady quavers. I hang up and go to peer out the window for the cat. Tuna. I'll put out a can of tuna. And go into the kitchen but all my tuna at the moment is the highest quality chunk white and so I hesitate but as luck has it there is a dusty old can of sardines which I open and run outside with. And place back in the corner to lure the little cat. I deadhead spent blossoms, diddle around pulling weeds, but mainly I am keeping an eye out for that cat; how can it resist the sardine scent? It can, however. It doesn't show.

But a real Girl Scout rampage has taken hold of my forty year old bones, and so I go on a bit of a search in the brush of the far back yard and even step over into the neighbor's. Yes, I am hearing a tiny crying, a tiny cat mewing. That is what's pulling me. I stop still. Nothing is darting toward the sardines.

And then a car pulls up in front and two blue-smocked women come out with boxes and a leash. I give them a big wave and put a silencing finger to my lips. They trudge down to me. Laborers. Unenchanted with the task in front of them. "Shh, listen," I whisper. And we all stand frozen and straining to hear. "Oh look," I say, for I catch sight of it, there in the neighbor's yard, nestled amid shrubbery and weeds. Its eyes glimmer out at us. "Sutu," orders Blue Smock One, a bottle blond of about fifty, and she stalks forward slowly yet firmly. "Here, Sutu," she calls, her voice all threat and steel. I watch and I smell failure. Sutu stares at the approaching woman and then turns and flees through a narrow-slatted fence. She slips off into nowhere. Evaporates. Blue Smock One and Two look at me, eyebrows 
perked up. Do they want me to join them in the chase? I beg off with a silent shrug which means look, look at my slim skirt, my wrong shoes to fence-climb, my lack of motivation cat-wise. The Blue Smocks leave, rattled. They drive off around the block. I go inside but keep an eye out; through an upper window I see them pick futilely through the weeds in the yard back beyond.

It is . . July now? I must quit frittering away time like this. I have senior theses to finish looking over, committee work to attend to. I must maintain my assistant professorship or the nine year old will be roofless in addition to fatherless. It's not funny but I still laugh to myself when I recall how my department head's gaze veered quickly off into the middle distance when I brought up the topic of tenure.

I prioritize my to-do list. At the top: conserve energy for the real business of life, to wit: Control my increasing bitchiness. Cut down on alcohol. Read at least one thesis, just to get started. Find a Bill Clinton type to be the nine year old's father!

That evening and the next evening and the next, the owners and family and the vet's office people come by and occupy themselves in an assortment of searches for the cat. They bring Sutu's identical brother as a lure. Doesn't work. The little old lady owner, very DAR, totters down my backyard hill; I worry about the possible crack crack cracking of her porcelain bones. She stands on the grass and maintains a sort of vigil, a keeping-in-contact with the last bit of earth the cat trod upon before running off. Why did you take me to that place and why did they tear out my claws, asks cat at a distance, keeping an eye on old lady owner, all blue-haired, all aged elegance, but something frantic, crazed about the eyes. "Sutu, Sutu," I hear her call in a deep threnody. I'd love to go and comfort the old woman but she'd be sure to smell the evening liquor on my breath. I could I suppose invite her in for a gin and tonic. No. Must conserve energy. Won't go outside. Energy better spent in talking to nine year old daughter for five to ten minutes. If I go outside and small talk with stranger about cat, all energy spent, and only able to lie down, drink at elbow, book on one side, paperwork on the other, will only have energy NOT to scream at nine year old not to bother one. Won't go outside. Issue resolved. Five minutes pass. "Mother," says nine year old accusingly to me prone on sofa, "you're not helping catch that poor cat." 
More calls about Sutu, more visits. I can read the signs; I can see that Blue Smock One, the vet's assistant, the peroxide user, is beside herself. She's told me her tale. Needs this job. Knows her days are numbered in the single digits if she doesn't get that cat back. How did it happen? Wasn't that damned woman, the Schnauzer's owner, partly to blame for leaving the front door unlatched? The vet doesn't see it that way. Wasn't there a clear sign on said door re carefully pulling it shut? Why had everything fallen on Blue Smock's head? The vet was so angry he wouldn't even look at her, and she knew he'd been in contact with his lawyer. Did she in fact need a lawyer here too? What would she do now-waitress again? How would she explain to her grandkids? She was fifty-two and had many years of work left in her, and to her grandkids she'd warbled about the wonders of tending animals, she'd made it sound as if she herself were the vet. Instead of merely a glorified pooper-scooper. Where was that goddamned cat? Why hadn't that stupid housewife grabbed it? Yes, yes, I can see Blue Smock One thinking this about me as she stomps into my backyard, tosses the trap down, and glares at the house. Little does she know that I am a professor; my annual contract so states. I could tell her and thus piss her off even more. But then I could explain tenure and the fact that I don't have it. I'm talking about the skin of my teeth, I could say, and the inexorable nature of monthly bills and the need to have milk in the fridge for the nine year old. That would mollify her, perhaps.

We saw the cat again this morning and once more of course were unable to snag it. The heat has arrived and yes, it's hellish. It's so hot that a sparrow, heat-befuddled, hit my leg as I was walking down the street to get some milk and a bottle of wine; I was out to stretch a bit and escape my air conditioned box. The nine year old was next to me. And, yes, a sparrow bumped into my leg and then bobbled off. We watched the little thing. "See, not a sparrow, not an eyelash, not the least lash lost; every hair is, hair of the head, numbered," I said out loud. The nine year old gave me a sour look. "Shall I recite more poetry?" I asked her.

"Shut up, Mother," she said. "I hate you and you know it," she told me. 
The nine year old is so heartbreakingly lovely now with her short black hair slicked down all over into a seal-sleekness, a Little RascalAlfalfa charm. "Please, angel," I said. "It's so hot." Most of my better self has worn off but I still do mis-remember snippets of Hopkins. And I thought oh ho, this slow bird will be a delectable dish for that lost little Sutu.

The nine year old, fatherless and slightly bereft, is sick about the cat in the heat, sick about the so-close-but-so-far-away aspect of the whole thing, and she's been giving me dirty looks for not befriending the old woman, for not bringing the old woman inside for tea. "Didn't you see her crying?" she asked me severely. Yes, yes, I can see the little girl is watching with those fresh and all observant eyes of hers. She puts bowls of ice water out in the far reaches of the yard. She sits hidden in the brush and waits for the cat to reappear. She knows wild cats are dangerous; she knows feral cats are to be avoided. This cat, she notices, looks innocent enough but when she thinks about it she realizes that there will be a point where the cat shifts from tame to wild, and she believes that point has been crossed or that it is being crossed now in a slow-motion/frozen-time sort of way. Yes, she's heard the cat crying, and then she's heard it stop and slither off. That is a step toward wild. She can feel it. The cat will be out there and a part of nature now. Maybe it will make friends with the squirrels and root around with them. The squirrels can teach the cat to relish nuts. How do I know this is all going on in the nine year old's head? I know because she told me. I heard her sighing in her bed one night and I asked her. "The old lady should just go home and not do any more of that dangerous crying," the nine year old said to me. "The old lady should just accept that the cat is a part of nature now."

"Do you want a pet kitten?" I asked her.

"Oh, Mother," she replied, "you've missed the point. You've missed the point by a thousand miles," she said, loosely quoting Huck Finn, something I taught her to do. She's a well-informed child. She knows that Mark Twain is Samuel Clemens. She cries when she thinks about Injun Joe trapped in that cave. 
Last night upon pulling into our drive after eating at a Chinese restaurant, the nine year old and I caught the cat in the glare of our headlights. Nine year old jumped out and hot-pursuited, but, alas, Sutu is fast. Nine year old ran back to me. "Next time I need a big net," she said. "I need like a big blanket to throw."

And the old lady: This will pass, she is thinking as she trespasses but yet again upon my property. It isn't trespassing. I've given her permission. But she's intruding on my envelope, on my Caucasian closedness. This will pass, she's thinking. I read it in the uprightness of her back, so admirably covered in a twinset dating from the fifties and imperceptibly moth-eaten. I think about her cedar closets. She's eighty-three. This will be a closed bubble in Sutu's life, she's thinking. Sutu is such a charming and lovely cat that she is sure to endear herself to some kindly humans; she will be taken in, she will be nurtured and comforted. The old lady knows this. And she knows that the pet shop in town carries a wide array of health food for cats, and Sutu is sure to share in that bounty. The only small concern she has is that perhaps a kernel of horror will be lodged permanently in Sutu's heart and she will be disfigured, unpleasant. But this will not happen; oh dear God, do your work here, prays the old lady, please, St. Francis, take care of your tiny creature. She's not Roman Catholic but she understands that St. Francis is not a subscriber to narrow tribalism.

Heat lightning and ninety-six degrees. A young man rings my doorbell and asks if I've seen a small black and white cat. He is dripping with sweat but his tone is slightly antiseptic and quite clearly lacking any hint of desperation. He is a hireling. That damned cat, I tell him. I've seen it and I've not seen it. I see it but I can't catch it, I say. Everyone knows it's hanging around here, I tell him. It's starting to bore me, I say. He gives me a puzzled and faintly frightened look, as if I've overstepped some boundary.

It's so hot. "Fuck," I say when I cut myself as I slice a lemon.

"Don't say that word, Mother," the nine year old tells me. "It's not civilized."

"Not civilized?" I ask. "I don't agree. I think it's very civilized. I think it's ancient and estimable." 
"Oh, Mother," the nine year old says, her voice heavy with disgust.

I smile at her personhood, her separateness and completeness. "It's so fucking hot," I say. The cut is nothing. I continue making lemonade.

"Oh, Mother," the nine year old says. "It's going to rain. Have patience."

The heat has pushed me into a fantasy realm: I suddenly realize sex with Bill Clinton would be delightful, a novelty. Has this popped into my head because the nine year old professes to admire him? No, noof course it has to do with these ongoing dog days, this ceaseless astronomical humidity punctuated with occasional downpours but with no real cessation of the steambath soupiness of the atmosphere. Bill, Bill of the delectable excess lipids, Bill, a creature sure to see the pros of sex during a heat wave such as this, a creature sure to perform admirably and happily even in this hazy hell.

I must help find Sutu, I must put down my cool beverage and aid in rescuing her from the wilds. I see now that this will iron out a wrinkle in my past, for when I was tiny I lost a new kitten; it ran into the bushes and never came out. I sat and sat and waited. I kept returning to that small opening in the low shrubs, but no: no tiny cat appeared. I waited for days. Disappeared. Vaporized by something in the brush. But I knew her tiny soul had gone to heaven so I was partially comforted. Or she'd found a rear exit and was happy with a family down the block. So I told myself, all five years old of me. The truth is-and my mother said nothing at the time; my mother held back this information - the truth is, the dogs got her. "The dogs got her," my mother, the JFK enthusiast, told me darkly years later. What dogs? We hadn't had any. But yes: anonymous voracious dogs lurk everywhere, always. And my heart skipped a beat at the sad news, for it was as if a loose brick had finally fallen a notch into a more comfortable resting place, and the cracking of the wall was continuing. What wall? I don't know. All I know is there was an ongoing cracking, and, yes, signs of structural weakness. JFK, for example. Bring up his name to a class of college freshmen, and there are blank stares, there is snickering, there is mention of Marilyn Monroe. "Ah yes, Marilyn," I say to them, "the goddess." Those blank stares, that snickering: the name Richard Nixon 
evokes the same response. But in his case Marilyn is nowhere. I smile at the block of anomie there in the air of every classroom. But it's not funny. It's probably just another symptom that my professor days are surely numbered.

Another young man is making the rounds of the neighborhood. But instead of ringing doorbells he is stapling fliers to telephone poles. I watch him head off and then I send the nine year old out to explore. She returns with eyes lit up. "A reward," she says. "One hundred dollars for safe return of Sutu." I nod. She runs into the backyard and searches anew; she comes back in and gets a ball of crimson yarn and takes it out and webs it through low bushes. After a while she comes back in and gives me a hard look, a warning. I know I am not to make any comment. I go out and read the notice: REWARD $\$ 100.00$ FOR SAFE RETURN. LOST CAT. Female black and white. Two yrs old and petite. Named "Sutu." Owner heartbroken. Call etc.

Blue Smock One comes by again on Sutu-search, and chats at me. Yes, the vet's given her notice. But she's got a new job lined up, she thinks, as a cashier in the supermarket-she'll get a discount on food, she'll be with an old chum of hers. She'll have to play it cool, she'll have to be frosty if certain bastards happen to use her line at the store; the vet, for example, shops there. A vet's assistant anyway is a disgusting and filthy job. She has to bathe carefully immediately after work each day; she can't lead a normal life. Not the right job for a grandmother, she tells me. I eye her narrowly. She is perhaps ten, twelve years my senior.

And then, miracle, I see the cat again, this time right next door, heading up the driveway. But I can't catch it, I am incapable, and so I quickly pick up the phone, I dial. But even as I'm hearing the ringing I sense something is slightly wrong and I realize it's the face, this strange cat in neighbor's yard has an all-white face. I pick up the flier. Sutu's face has a black blotch from the forehead down to the nose. No, this cat isn't Sutu. But now the sixty year old daughter is on the line and I'm describing this particular cat. No, that's not it, she says, and she pauses and so do I and I gather we're both thinking we may have been pursuing the wrong cat from the start. But no, that first cat 
we saw had the markings; that was Sutu. The pause lengthens. I see my drink making a large wet blotch on the nine year old's soccer application. I cluck into the phone. Well, I say, I'll still keep an eye out. Yes, do, says the sixty year old daughter, and we hang up. I try to blot dry the soccer application; I look at it to see if it's still legible. Damned cat. Odd how attached people grow to animals. My father never trusted cats, that I recall. I wonder why. I wonder what bad experience he had with them. The nine year old slips down the stairs and out of the house before I have a chance to stop her. Do you in fact really want to play soccer, I meant to ask. Will it be worth the expense of the cleats and the shin guards? And all those endless dreary practices?

The old woman is rooted in my backyard again and I can read her mind so clearly, it's the blue of a desert sky: I need my cat, I need my cat, I need my cat. I can't stand that little pool of sadness, I can't stand Sutu lost and confused and blaming me for this tragic chain of events, I can't stand it, oh Sutu, come back, I need you. Oh dear God, I've been a good woman for eighty-three years, I let you take little Patrick, dear God, give me back Sutu. Sutu can't understand. God, God, dear Jesus can't you see it makes no sense, it only creates sadness that Sutu is out there and confused and probably a kernel of hate growing in her heart, hate for the terrible vet who did it to her. I need to comfort her, I need the opportunity. I need my cat, my kitten, she's just two, she's tiny still. Please dear God. Answer my prayers. There are so few things I've asked of you and this is purely right, this is purely goodness: that small creature should be comforted, and comfort is here; comfort is with me. Do it, God, do it. Damned useless incompetent St. Francis has done nothing, and so I turn to you, the all-powerful.

So the vet's office continues to put out traps. Blue Smock One has been replaced by a super-efficient lovely-young-thing. Athletic and goddess-limbed. I watch her heft a trap into the backyard. Her lipids, they're all flowing smoothly and powerfully. That was me, me, not so very long ago. And I can feel the nine year old aimed that way, sure as an arrow.

I wake up early the next morning and think about the trap and so I 
go out to look at it. Yes, the two side panels are down, there's something caught. But I'm afraid to touch the thing. I find a stick in the yard and push the trap slightly to the side. I bend down and peer in. It's a furry young possum. Possum? What do $I$ know of fauna? But possum, yes, the identification comes to me with great certainty. Poor thing. Its mouth is open and so are its eyes but it's immobilized in fear and panting quickly. What sharp perfect tiny teeth it has. I think briefly about letting it free but realize I can't, it would be foolhardy, the little thing would probably instantly sink those fangs into my ankle. That half-assed vet's office. They need a professional trapper. I go back into the house and start the coffee. The nine year old is up and about, I hear her moving around. She clatters down the stairs. "Sweetie-pie," I say, "how about skipping soccer this year. Think of all the lovely fall weekends it eats up! How about going on a movie binge with me instead. We can do old B movies in Manhattan every Saturday afternoon and then have Indian food."

"Oh, Mother," the nine year old says, scowling. I stare at her and marvel at her beauty. I reach out to stroke her lovely head but she bats my hand away.

"Should I tell you why your father left us?" I ask her.

"No, no, no," she says. "You've already told me. I can't keep hearing that stupid story."

I nod and bite my tongue. "Oh," I say, remembering, "go see the possum in the trap." She flies out into the yard. I don't bother to call the vet's office; it's their job to monitor the damn thing.

It's so hot it's like we're walking around balancing atop metal grates over white-hot coals, we're on the grill of a huge barbecue and the fire of the barbecue is hell. This image comes to me in a dream, a sleeping dream. My heat-induced daydreams are far pleasanter and sometimes involve Bill Clinton. Yes, if stuck on an elevator with him, I'd have sex, yes, if I bumped into him on the beach in Tahiti, I'd have sex. We'd both be scantily clad; it'd be easy. Our lipids; they're well enough matched right now, age-wise. I'd go ahead and conceive a love-child but only of course as long as Clinton's in office. It would be a novelty, a subversion of certain dominant paradigms. But the heat continues. There was the little confused sparrow that day, and today 
when I went to the campus to pick up mail I noticed a tiny mouse crouching on the sidewalk ... not moving, just crouched and bent over, its dime-sized head hidden in its minute paws, crying for lack of water. I wanted to push at it gently with my toe so it would move over into the cool grass but I didn't in case it might turn suddenly and take a big bite out of my ankle.

Doorbell ring. Annoying. I go answer. It's a man about fifty, handsome and outdoorsy looking. I catch him staring with bemusement at the picture of the Rajah prince taped for adornment on my mailbox. "Yes, yes, it's a Rajah prince," I say. Because, fuck, I wasn't going to let that damn clichéd eagle greet everyone who comes to my door. But here this person was, scowling at the Indian as if it were the antiChrist. He transfers his wary look to me, the wariness drops, and he gives me the old once-over. Yes, I'm attractive, I know, I know.

"Hello," he says, "I'm here for Sutu, I'm a trapper," and he hands me a card. I look at it. There's a cartoon of a grinning forest ranger leading off a raccoon, a squirrel, and a skunk.

"Hmm," I say. "I was just telling my daughter, just yesterday, that a real hunter-trapper is the only one who'll get that cat, a true professional." He smiles and asks permission to set a bunch of traps in my backyard. I see his assistant already removing them from the back of a truck, four, five of them.

"Go ahead," I say, "go right ahead. Oh, we've seen her, yes, she looks good, healthy. We saw her, what was it, just Saturday night. She looks like she's doing fine." I notice a tiny shadow cross his face and I guess he might be more pleased if Sutu was slightly wounded at this point, slightly slowed down and ready to come in out of the metaphorical cold.

"Well," he says, "she won't stay alive very long, a big raccoon will get her. She's an indoor cat." I note that this fellow always makes determined eye contact with me. It must be a principle of huntingtrapping.

The assistant walks by with some of the cages. "Those look just like what the vet used," I say.

"Well, those people don't know what they're doing," the hunter says. "They don't know anything about catching an animal and they've 
probably made things a lot worse. This family," he says, "this family is just sick about the loss of this cat."

I can hear in his tone the sudden shift into declamation, the affected bathos. And so of course I know who is paying the bill for this huntertrapper who I'm sure is an expert on moose migration, who looks fat and glossy and is probably riding high on the current chic of fly fishing and probably has a walletfull of catch and release instructor cards, too. I'm just fantasizing, of course. And he's not fat. He's attractive, actually. Older than Bill Clinton, but then this guy's lipids are more under control. There's a tautness here that I could tolerate. I catch hold of myself so that this hunter-trapper won't sniff out the chemicals I must now be emitting.

"Go ahead," I say. "Just come and go. It's fine with me. I hope you catch her."

"We'll be by three times a day to check the traps," he tells me. He smiles good-bye and walks toward his truck but turns at the last moment to call out, "You've got my card."

I half laugh. Yes, we've communicated.

Uh-oh. The old woman, her osteos depleted no doubt but still she's so very upright: look at her standing there with her hands on her hips, her feet growing roots into my soil as she sinks into some sort of Zen state in desiring her damned cat to return to her. Well! She has a purpose in life.

Why do I feel so good? It's still so diabolically hot. Maybe it feels so good because last night $I$ had the most incredibly vivid dream of being an actress, elegant and accomplished. And I was cast opposite Jack Nicholson, and we engaged in something called "lap sex" in one particular scene. We were fully clad but he pulled me onto his lap and started discussing some murder plot we were involved in, and as he talked to me he kept pumping/bumping up and down and into me, and at first I thought he was just being friendly-this film was very Tarantino-esque and improvised-but then I realized his humping meant business and I was getting carried away and so was he, and finally he orgasmed on camera but inside his pants and I jumped off him and he got a Kleenex and sopped up what was inside his pants, all on camera. 
The film was rated " $R$ " and reviewers mentioned no nudity but, yes, lap sex.

Anyway, it was a good dream, and I awoke contented and happy. And then I remembered my hunter-trapper. Yes. Jack Nicholson can play him in the film version. That would be quite satisfying.

I have the hunter-trapper's phone number. I turn his funny little card over in my hand. I can call him whenever I like, at any hour. Rush over, rush over, I can say, the trap is full. And then when he gets here and finds nothing and looks at me sideways I can laugh at him and say, oh, I made a mistake.

That hunter-trapper. He left those traps on Thursday latish, it was Thursday afternoon. I've seen him running to and fro, to and fro. And here it is Saturday morning and sure as hell I'm staring into one of the traps and there is Sutu. Yes, it's she, the black blotch is dripping down between her eyes. I walk slowly into the house. Ooh, that huntertrapper. Does good work. Quick and to the point. I've left his card by the phone, and I start to dial his number. No. I'll call the owner. I have no real interest in telling the hunter-trapper he's nailed his prey. Let him learn about it secondhand. I'll call the old ladies. And so I do. They are overjoyed.

"We're coming to get her," they say. "We're coming right now."

"Fine," I say. We stay on the line for a moment. "Take the trap in the car with you," I tell that sixtyish woman. "Don't try to let her out in the backyard," I say. "Just to be on the safe side."

"Oh, yes," she says, "you're right."

I leave the house and lock it up before they come. I have no real interest in witnessing the reunion. Uh-oh. The nine year old. Off at the library. Will her heart be broken if she misses this? Should I rush over and collect her? I don't. Instead, I drop off the soccer application, just slightly late. I sigh deeply at the prospect of all those friendly parents on the sidelines, roaring out their children's names. And me among them, but mainly silent. Still, there is no point in cursing round inflatables. 
I keep thinking about Bill Clinton and his delectable lipids. To think that during my lifetime there'd be so very sexually attractive a president and in my age category decade-wise. The beauty part is that I can oh so efficiently transfer this lust to the hunter-trapper, a Perot supporter, no doubt; maybe even a militia sympathizer. Certainly someone with a positive attitude toward the NRA, and quite possibly a soul who considers Newt Gingrich an eminent intellectual. Should I really fantasize sex with such a one? The dirty look he gave the Indian Rajah on my mailbox ... it's not an Indian deity, it's not Blue Krishna. It's more an Indian soldier type, someone somewhat akin to this very huntertrapper. I'm not fantasizing in any full-blown way, however; I'm not thinking about thrashing body parts or well-toned ripples agleam with sweat. I'm not thinking of basking in the afterglow. No. I'm more just admiring upper body heft inside that red polo shirt of his, and his ability to pull that big trap out of the truck with one hand; I'm appreciating the lovely golden hair of his forearms. A hunter-trapper! How delightful to possess such a concrete identity, such a real need for a multi-pocketed khaki vest.

The fact is, the hunter-trapper called me and asked me to keep him in mind if I needed his services in the future. "Still have my card?" he queried.

"Yes," I said slowly and carefully. "I think so." I was aware of the importance of keeping things at arm's length. "And may I ask how you got my number?" I asked him.

"Sutu's owner," he said briskly. "Part of the package." And then he asked me out to dinner, which stunned and pleased me, but I immediately begged off, of course.

"Rain check, then," he said with his sportsman's upbeat certainty. "I'll call again."

So there's that. Dinner. It might be an amusing novelty.

Or else of course I can always maintain my monastic lifestyle. That's another pleasurable alternative here. Monasticism goes better with my bereft untenured professor persona. (My chairman told me I'm solid for one more year, but beyond that . . . he shrugged his shoulders in beauteous world weariness.)

Sutu is at home again, caged snugly inside the old lady's house. Her wandering days are over. The nine year old. I'll ask her: should we go 
out to get you new soccer cleats? Should we go to the Humane Society and pick out a stray? Should we sit around the house and read, and feel like a pair of old shoes? What shall we do? You pick. 